\title{
Factors associated with the stigma-discrimination complex towards healthcare workers among university students during the coronavirus pandemic in Mexico
}

\author{
Carlos Arturo Cassiani-Miranda, $\mathrm{MSc}^{1}$ \\ Isabel Álvarez-Solorza, $\mathrm{MSc}^{2}$ \\ Adalberto Campo-Arias, $\mathrm{MSc}^{3}$ \\ Yinneth Andrea Arismendy-López ${ }^{4}$ \\ Andrés Felipe Tirado-Otálvaro, $\mathrm{PhD}^{5}$ \\ Lilia Patricia Bustamante-Montes, $\mathrm{PhD}^{6}$ \\ María Juana Gloria Toxqui-Tlachino ${ }^{7}$
}

${ }^{1}$ Associate professor, Programa de Medicina, Facultad de Ciencias de la Salud, Universidad de
Santander $\quad$ (UDES), Bucaramanga, Colombia. $\quad$ (ca.cassiani@mail.udes.edu.co) https://orcid.org/0000-0002-2288-1027

${ }^{2}$ Associate professor, Facultad de Enfermería y Obstetricia de la Universidad Autónoma del Estado de México, Toluca, Mexico. (ialvarezs@uaemex.mx) https://orcid.org/0000-0002-13401300

${ }^{3}$ Associate professor, Programa de Medicina, Facultad de Ciencias de la Salud, Universidad del Magdalena, Santa Marta, Colombia. (acampoa@unimagdalena.edu.co). https://orcid.org/00000003-2201-7404

${ }^{4}$ Medical student, Programa de Medicina, Facultad de Ciencias de la Salud, Universidad de Santander (UDES). (buc18181056@ mail.udes.edu.co). https://orcid.org/0000-0002-7363-6777

${ }^{5}$ Titular professor, Facultad de Enfermería, Universidad Pontificia Bolivariana, Medellín, Colombia (felipe.tirado@upb.edu.co). https://orcid.org/ 0000-0001-9010-1494

${ }^{6}$ Titular professor, Decanato de Ciencias de la Salud, Universidad Autónoma de Guadalajara, Guadalajara, México (patriciiab@yahoo.com.mx). https://orcid.org/0000-0002-8529-9982

7Associate professor, Facultad de Enfermería y Obstetricia de la Universidad Autónoma del Estado de México, Toluca, Mexico (gtoxqui59@yahoo.com.mx). https://orcid.org/0000-0003$1307-2428$ 
medRxiv preprint doi: https://doi.org/10.1101/2021.03.14.21253547; this version posted March 17, 2021. The copyright holder for this preprint (which was not certified by peer review) is the author/funder, who has granted medRxiv a license to display the preprint in perpetuity.

It is made available under a CC-BY-NC-ND 4.0 International license.

Corresponding author: Adalberto Campo-Arias, Universidad del Magdalena, Carrera 32 No. 2208, Santa Marta, Colombia (Código postal 470004) Teléfono: 5754381000 Ext. 1338. Email: acampo@unimagdalena.edu.co

Funding: The Research Vice-Rectory of the Universidad del Magdalena supported AC-A through Resolution 266 of 2020.

\begin{abstract}
The COVID-19-related stigma towards healthcare workers negatively influences their performance and job satisfaction, and well-being. The frequency of COVID-19-related stigma towards healthcare workers and its associated factors has not been sufficiently investigated. The objective was to determine the frequency and variables associated with COVID-19-related stigmatisation towards health workers in emerging-age university adults in Mexico. Analytical and cross-sectional study using an online questionnaire in 1,054 students between 18 and 29 years of age. Demographic variables, religiosity, fear of COVID-19 and stigma-discrimination related to COVID-19 towards healthcare workers were analysed. The latter was set as the dependent variable, while demographic variables, religiosity and high fear of COVID-19 were the independent variables. For the association between the variables, a binomial and logarithmic generalised linear model was designed to calculate the adjusted prevalence ratios. The proportion of high stigma-discrimination was $12.4 \%$, and this was associated with a high fear of COVID-19 (APR 1.51, 95\% CI 1.06 to 2.23). The main limitations were the cross-sectional nature, social desirability bias, non-probabilistic sampling. The results highlight the importance of establishing programmes to reduce COVID-19-related stigmatisation towards healthcare workers.

Keywords: Social Stigma, Risk Factors, Health Personnel, Students, COVID-19.

\section{Introduction}

Infectious disease outbreaks are associated with negative psychological and social consequences comparable to their biological outcomes (Saeed et al., 2020). Among these consequences, one of the most impactful is stigma-discrimination, as it affects health-related outcomes and is a barrier to accessing health services (Asadi-Aliabadi et al., 2020). These negative social attitudes and behaviours affect various segments of society, such as patients, families, and healthcare providers (Asadi-Aliabadi et al., 2020).
\end{abstract}


medRxiv preprint doi: https://doi.org/10.1101/2021.03.14.21253547; this version posted March 17, 2021. The copyright holder for this preprint (which was not certified by peer review) is the author/funder, who has granted medRxiv a license to display the preprint in perpetuity. It is made available under a CC-BY-NC-ND 4.0 International license .

During the rapid spread of SARS-CoV-2 infection, it has been observed that health systems have faced a critical overload on human resources (Sorokin et al., 2020), which are mainly due to psychological distress (Ramaci et al., 2020) associated with the so-called stigma-discrimination complex (SDC) (Campo-Arias \& Herazo, 2015; Cassiani-Miranda et al., 2020).

Stigma is defined as a characteristic or trait attributed to someone or something and usually implies a negative connotation (Goffman, 2009). This trait represents a discrediting label that makes stigmatised people feel alienated from society, and labelling can turn into pigeonholing and stereotyping, leading to discrimination and loss of status (Link \& Phelan, 2001).

In the context of the COVID-19 pandemic, people are stigmatised because of a perceived link to the disease, shaping the concept of COVID-19-related stigma, particularly affecting healthcare workers (HCWs) (Chopra \& Arora, 2020). In infectious disease outbreaks, fear and misinformation are variables that explain stigmatisation (Schoch-Spana et al., 2010; Abuhammad et al., 2020). SDC interferes with the diagnosis and treatment process by disrupting communication, individual identity and sense of free will (Mawar et al., 2005). People who feel stigmatised tend to avoid certain behaviours perceived to increase stigma, such as refusing to be tested for COVID-19, because a positive result may be the label they consider stigmatising (Fischer et al., 2019).

Stigma is a barrier to effective infectious disease prevention and control mechanisms and can affect the stigmatised group and a wide range of people around them with a particular impact on HCWs (Perry \& Donini-Lenhoff, 2010; Ramaci et al., 2020). For example, perceived stigma discourages infected persons and affects healthcare workers themselves (Almutairi et al., 2018) and can be an additional stressor (Ramaci et al., 2020).

Complementarily, negative attitudes may affect care-seeking and increase the collateral damage of COVID-19 (Cassiani-Miranda \& Campo-Arias, 2020). More than 200 COVID-19related attacks on HCWs have been documented (Bagcchi, 2020). In these incidents, HCWs experienced social isolation, public insults or harassment, refusal to use public transport and eviction from the housing. These violent behaviours in the pandemic context towards HCWs shape a specific stigmatisation process called Coronavirus Disease-Related StigmaDiscrimination-Complex-towards Healthcare Workers (CDRSDCHCW) (Campo-Arias et al., 2020; Stangl et al., 2019; Ransing et al., 2020). 
medRxiv preprint doi: https://doi.org/10.1101/2021.03.14.21253547; this version posted March 17, 2021. The copyright holder for this preprint (which was not certified by peer review) is the author/funder, who has granted medRxiv a license to display the preprint in perpetuity. It is made available under a CC-BY-NC-ND 4.0 International license .

These stigmatisation experiences negatively influence HCWs' performance, job satisfaction, self-efficacy and general well-being (Monterrosa-Castro et al., 2020; Ramaci et al., 2020; Teksin et al., 2020). Besides, it is crucial to consider that SDC tends to persist over time, easier to consolidate than to eradicate (Dar et al., 2020). Therefore, CDRSDCHCW should be rigorously addressed by healthcare professionals, providers, and health authorities (Adiukwu et al., 2020). Having a valid and reliable instrument to measure CDRSDCHCW (Campo-Arias et al., 2020) could improve the identification of the phenomenon and associated variables and allow public health decision-makers to design informed and effective interventions. Despite the potential impact on the quality of life of HCWs, CDRSDCHCW and its associated factors have not been sufficiently investigated (Mostafa et al., 2020).

This study aimed to determine the frequency and explore variables associated with stigma discrimination complex related to coronavirus disease towards healthcare workers during the pandemic in a sample of emerging-age university adults in Mexico.

\section{Method}

Study design and ethical considerations

A research ethics committee approved this cross-sectional, analytical study of a Colombian state university (Act 004 of the extraordinary session of 13 May 2020). Participants gave informed consent in congruence with national and international standards (Colombian Ministry of Health, 1993; World Medical Association, 2018).

Population and sample

An online questionnaire solicited the participation of students from a Mexican state university. A sample of at least 384 participants was expected since this sample size was calculated for low prevalences of the dependent variable of $10 \%$, with a margin of error of $3 \%$, or as high as $50 \%$, with a margin of error of 5\%; in both cases with a $95 \%$ confidence level (Hernández, 2006). This number of participants would explore some associations with acceptable confidence intervals (Katz, 2006). Students between 18 and 29 years of age (emerging age) were included (Arnett, 2000).

\section{Measures}

The research questionnaire included demographic variables (age, gender, marital status, education level, occupation, marital status and income level), religiosity, fear of coronavirus disease and stigma-discrimination related to coronavirus disease towards $\mathrm{HCWs}$. 
medRxiv preprint doi: https://doi.org/10.1101/2021.03.14.21253547; this version posted March 17, 2021. The copyright holder for this preprint (which was not certified by peer review) is the author/funder, who has granted medRxiv a license to display the preprint in perpetuity. It is made available under a CC-BY-NC-ND 4.0 International license .

\section{Stigma-discrimination complex related to coronavirus disease towards healthcare workers}

It was quantified with the Stigma-Discrimination Scale Related to Coronavirus Disease towards Healthcare workers. This tool is a five-item instrument with a dichotomous response pattern (Campo-Arias et al., 2020), which resulted from a process of adaptation of the Tuberculosis Stigma Scale (Upegui-Arango \& Orozco-Vargas, 2019). The instrument presents a unidimensional structure with acceptable internal consistency, Kuder-Richardson coefficient of 0.67 (Campo-Arias et al., 2020). Each affirmative response is assigned one point; overall scores can be between 0 and 5. Scores between 0 and 2 were classified as low stigma-discrimination related to coronavirus disease, and scores between 3 and 5 were classified as high stigmadiscrimination according to the research group's criteria. In the present study, the KuderRichardson test was 0.68 .

\section{Religiosity}

Religiosity was quantified with the Francis 4-item short scale of attitude towards Christianity (Francis-4). This instrument consists of four items exploring attitude towards God, Jesus and prayer. The items offer five response options from completely disagree to completely agree, scored from zero to four, with overall scores between 0 and 16. This instrument has shown excellent dimensionality and internal consistency in previous studies (Campo-Arias \& CeballosOspino, 2020). Global scores between 0 and 12 were rated as low religiosity and those between 13 and 16 as high religiosity, based on previous studies in Colombia (Campo-Arias et al., 2020). In the present study, the scale showed a Cronbach's alpha of 0.97.

\section{Fear of coronavirus disease}

It was quantified with the five-item version of the Fear of COVID-5 (Cassiani-Miranda et al., 2021) adapted and validated by the research team in the general Colombian population original 7-item Fear of COVID-19 Scale (Ahorsu et al., 2020). The Fear of COVID-5 has four response options that are scored from 0 to 3. The Spanish version of this instrument has shown adequate internal consistency, Cronbach's alpha of 0.75 (Cassiani-Miranda et al., 2020). In the present study, the scale showed a Cronbach's alpha of 0.78 . The scale allows total scores between 0 and 15. Scores equal to or higher than four were categorised as high fear related to COVID-19, like a similar study in a Colombian population (Cassiani-Miranda et al., 2020).

Procedure 
medRxiv preprint doi: https://doi.org/10.1101/2021.03.14.21253547; this version posted March 17, 2021. The copyright holder for this preprint (which was not certified by peer review) is the author/funder, who has granted medRxiv a license to display the preprint in perpetuity.

It is made available under a CC-BY-NC-ND 4.0 International license .

An electronic questionnaire was sent via the institutional mail server. The invitation to participate in the study was sent to all persons linked to the university. The anonymous questionnaire took no more than ten minutes to complete. Data was collected between 3 July and 10 August 2020.

Data analysis

Frequencies and percentages for qualitative variables and measures of central tendency and dispersion for quantitative variables [mean (M), standard deviation (SD), median (Me) and interquartile range (IQR)] were described according to the distribution of the data. For the analysis, CDRSDCHCW was considered the dependent variable, while demographic variables, religiosity, and high fear of COVID-19 were considered independent variables. For variables associated with CDRSDCHCW, prevalence ratios (PR) with their 95\% confidence intervals (95\% CI) were calculated. Subsequently, significant variables in the bivariate analysis, those that met the Hosmer-Lemeshow criteria (Hosmer et al., 1991) and those with biological plausibility with the outcome, were entered into a generalised linear model with a binomial distribution and $\log$ link function to calculate adjusted PRs (APRs) explaining the association between covariates and CDRSDCHCW (Bastos et al., 2015). The analysis was completed in Jamovi version 1.2.27.0 (Jamovi Project, 2020).

\section{Results}

A total of 1,054 students participated $(M=20.7, S D=2.2, \mathrm{Me}=20, \mathrm{IQR} 19-22)$. Categorical findings and population characteristics are presented in table 1.

Table 1. Demographical characteristics of the sample.

\begin{tabular}{lcc}
\hline Variable & $\mathrm{n}$ & $\%$ \\
\hline Gender & & \\
Female & 852 & 80.8 \\
Male & 202 & 19.2 \\
\hline Stable couple (marital status) & & \\
Yes (free union or married) & 58 & 5.5 \\
No (single, separated or widowed) & 996 & 94.5 \\
\hline Have children & & \\
Yes & 60 & 5.7 \\
No & 994 & 94.3 \\
\hline Bachelor's degree & & \\
Yes & 1046 & 99.2 \\
No & 8 & 0.8 \\
\hline
\end{tabular}




\begin{tabular}{lcc} 
Employee & & \\
Yes & 156 & 14.8 \\
No & 898 & 85.2 \\
\hline Healthcare worker & 171 & 16.2 \\
Yes & 883 & 83.8 \\
No & & \\
\hline Low income (Mexican classification) & 448 & 42.5 \\
Yes & 606 & 57.5 \\
No & & \\
Low religiosity & 802 & 76.1 \\
Yes & 252 & 23.9 \\
No & & \\
\hline Elevated fear COVID-19 & 254 & 24.0 \\
Yes & 801 & 76.0 \\
No & & \\
\hline Stigma towards healthcare workers & 131 & 12.4 \\
Yes & 923 & 87.6 \\
No &
\end{tabular}

Scores for religiosity were observed between 0 and $16(\mathrm{M}=8.53, \mathrm{SD}=5.45, \mathrm{Me}=9, \mathrm{IQR}$ =4-12); for fear of coronavirus disease they were between 0 and $15(\mathrm{M}=2.35 ; \mathrm{SD}=2.51 ; \mathrm{Me}=$ 2 ; and RIC $=0.25-3)$; for stigma-related discrimination between 0 and $5(\mathrm{M}=0.92, \mathrm{SD}=1.26$, $\mathrm{Me}=0, \mathrm{IQR}=0-1) \cdot 12.4 \%(\mathrm{n}=131)$ of participants scored for high stigma-discrimination. A statistically significant association was found between CDRSDCHCW and the high fear of COVID-19. See table 2.

Table 2. Associate factors with high stigma-discrimination in adult emergent students in México.

\begin{tabular}{lcc}
\hline Item & PR $(95 \%$ CI $)$ & APR (95\%) \\
\hline Female gender & $1.32(0.38-2.07)$ & $1.26(0.82-2.05)$ \\
Stable couple & $0.97(0.47-1.98)$ & $0.98(0.38-2.14)$ \\
Have children & $0.94(0.46-1.91)$ & $0.86(0.33-1.85)$ \\
Bachelor's degree & $0.99(0.16-6.16)$ & $0.96(0.25-15.97)$ \\
Employee & $1.10(0.71-1.70)$ & $1.09(0.67-1.66)$ \\
Healthcare worker & $1.04(0.68-1.60)$ & $0.97(0.61-1.48)$ \\
Low income & $1.29(0.94-1.78)$ & $1.33(0.96-1.83)$ \\
Low religiosity & $0.83(0.58-1.18)$ & $0.86(0.61-1.25)$ \\
Elevated COVID fear & $1.55(1.11-2.17)$ & $\mathbf{1 . 5 1 ( \mathbf { 1 . 0 6 } - 2 . 2 3 )}$ \\
\hline
\end{tabular}

\section{Discussion}


medRxiv preprint doi: https://doi.org/10.1101/2021.03.14.21253547; this version posted March 17, 2021. The copyright holder for this preprint (which was not certified by peer review) is the author/funder, who has granted medRxiv a license to display the preprint in perpetuity. It is made available under a CC-BY-NC-ND 4.0 International license .

In the present study, $12.6 \%$ of Mexican emerging-age students reported high CDRSDCHCW and associated high fear of COVID-19. The high frequency of CDRSDCHCW observed is similar to that found in other studies that have reported high levels of COVID-19related stigma towards healthcare workers (Abuhammad, 2020; Cassiani-Miranda et al., 2020; Sotgiu \& Dobler, 2020). These findings could be explained by the fact that SARS-CoV-2 is more contagious than other stigmatised diseases (Schwartz et al., 2020). The perception of a global pandemic experience combined with economic crisis scenarios (Saeed et al., 2020) could also explain the high stigmatisation level.

The development of stigma/discrimination is related to cultural, educational, religious, personal, economic and environmental variables (Demirtaş-Madran, 2020). Thus, in the present study, a statistically significant association was observed between high CDRSDCHCW and a high level of fear of COVID-19. These results are compared with similar studies where fear of contagion is a variable that generates prejudice, stereotypes and discrimination (Abuhammad, 2020; Cassiani-Miranda et al., 2020). Indeed, HCWs around the world, in both low- and middleincome countries, face SDC, mediated mainly by fear of infection (Sotgiu \& Dobler, 2020). However, the association between CDRSDCHCW and other variables may take on a different connotation according to methodological issues. For example, in a sample of 91 COVID-19 survivors in India, perceived stigma was significantly higher in men than women; enacted stigma and internalised stigma were associated with a high education and occupation level. (Dar et al., 2020). In this study, Dar et al. measured stigma using a stigma questionnaire adapted from the Ebola-related stigma questionnaire derived from the Berger HIV stigma scale (Jeyaseelan et al., 2013). However, unlike our study, the stigma assessment in this sample did not target stigmatisation experiences directed towards $\mathrm{HCW}$ s but was instead a general stigma measure, explaining the differences in associations with the present study.

Another predictor of the stigma that we included in this study was religiosity, although no statistical association with CDRSDCHCW was found. The influence of religiosity on COVID-19 management, especially in developing countries, may generate certain practices that are deleterious to established precautionary measures against the disease; furthermore, the belief that life and death are controlled by the "Almighty", which is also configured as a religious stigma that may impact precautionary measures against COVID-19 (Hashmi et al., 2020). This 
medRxiv preprint doi: https://doi.org/10.1101/2021.03.14.21253547; this version posted March 17, 2021. The copyright holder for this preprint (which was not certified by peer review) is the author/funder, who has granted medRxiv a license to display the preprint in perpetuity.

It is made available under a CC-BY-NC-ND 4.0 International license.

observation suggests that the relationship between stigma and religiosity is more complex and may be mediated by other types of variables not explored in this study.

Implications

The CDRSDCHCW could disrupt patient identification and surveillance and generate considerable negative impacts on pandemic control and management (Asadi-Aliabadi et al., 2020). Therefore, predicting the stigma-related consequences of COVID-19 is essential in planning prevention measures (Brooks et al., 2020; Liu et al., 2020). Consistent with previous data (Ramaci et al., 2020), this study's findings suggest that the CDRSDCHCW study can provide insight into the stigmatisation process associated with emerging infectious diseases and the possible consequences of such stigmatisation.

Pandemic-related stigmatisation is a violation of human rights (Demirtaş-Madran, 2020) and undermines basic levels of dignity, provokes new types of vulnerabilities, and reinforces preexisting inequalities. (Ugidos et al., 2020; Ramaci et al., 2020). Therefore, knowing the frequency and correlates of CDRSDCHCW provides valuable information for designing interventions to reduce social stigma towards HCWs (Chopra \& Arora, 2020; Demirtaş-Madran, 2020). In this perspective, an inclusive and rights-based policy approach to address COVID-19 should not only focus on eliminating the disease or interrupting transmission but also address stigma and intersecting vulnerabilities, as well as the conditions that promote or perpetuate stigma (Bologna et al., 2021; Qin X \& Song, 2021). Consequently, to be equitable and practical, the global response to COVID-19 requires that stigma becomes a higher priority on the public health agenda (Roelen et al., 2020).

\section{Limitations}

The cross-sectional nature of this study limits the strength of the associations assessed, and it is not possible to make causal relationships between variables. On the other hand, social desirability bias may have limited participants' responses for fear of being stigmatised, although to reduce this, we tried to preserve maximum confidentiality. The results are not generalisable to the Mexican university population, as the convenience sample was restricted to a single university. The study's quantitative nature does not allow us to explore other manifestations of the stigmatisation process related to COVID-19 so that qualitative studies would enrich the state of knowledge in this area.

Conclusions 
medRxiv preprint doi: https://doi.org/10.1101/2021.03.14.21253547; this version posted March 17, 2021. The copyright holder for this preprint (which was not certified by peer review) is the author/funder, who has granted medRxiv a license to display the preprint in perpetuity. It is made available under a CC-BY-NC-ND 4.0 International license.

The COVID-19-related stigmatisation towards health workers among emerging-age adult university students in Mexico is considerable and is associated with a high level of fear of COVID-19. These results highlight the importance of establishing intervention programmes that address COVID-19-related stigma towards healthcare workers and their potential consequences.

\section{References}

Abuhammad, S., Alzoubi, K., \& Khabour, O. (2020). Fear of COVID $\square 19$ and stigmatisation towards infected people among Jordanian people. International Journal of Clinical Practice, e13899. https://doi.org/10.1111/ijcp.13899

Adiukwu, F., Bytyçi, D. G., Hayek, S. E., Gonzalez-Diaz, J. M., Larnaout, A., Grandinetti, P., Nofal, M., Pereira-Sanchez, V., Ransing, R., Shalbafan, M., Soler-Vidal, J., Syarif, Z., Teixeira, A. L. S., da Costa, M. P., Ramalho, R., \& Orsolini, L. (2020). Global perspective and ways to combat stigma associated with COVID-19. Indian Journal of Psychological Medicine, 42(6), 569-574. https://doi.org/10.1177/0253717620964932

Ahorsu, D. K., Lin, C. Y., Imani, V., Saffari, M., Griffiths, M. D., \& Pakpour, A. H. (2020). The Fear of COVID-19 Scale: Development and initial validation. International Journal of Mental Health and Addiction. https://doi.org/10.1007/s11469-020-00270-8

Almutairi, A. F., Adlan, A. A., Balkhy, H. H., Abbas, O. A., \& Clark, A. M. (2018). "It feels like I'm the dirtiest person in the world." Journal of Infection and Public Health, 11(2), 187191. https://doi.org/10.1016/j.jiph.2017.06.011

Appleby, A., Wilson, P., \& Swinton, J. (2018). Spiritual care in general practice: Rushing in or fearing to tread? An integrative review of qualitative literature. Journal of Religion and Health, 57(3), 1108-1124. https://doi.org/10.1007/s10943-018-0581-7

Arnett, J. J. (2000). Emerging adulthood: A theory of development from the late teens through the twenties. American Psychologist, 55(5), 469-480. https://doi.org/10.1037/0003066x.55.5.469

Asadi-Aliabadi, M., Tehrani-Banihashemi, A., \& Moradi-Lakeh, M. (2020). Stigma in COVID19: A barrier to seek medical care and family support. Medical journal of the Islamic Republic of Iran, 34, 98. https://doi.org/10.34171/mjiri.34.98

Bagcchi, S. (2020). Stigma during the COVID-19 pandemic. The Lancet Infectious Diseases, 20(7), 782. https://doi.org/10.1016/s1473-3099(20)30498-9 
medRxiv preprint doi: https://doi.org/10.1101/2021.03.14.21253547; this version posted March 17, 2021. The copyright holder for this preprint (which was not certified by peer review) is the author/funder, who has granted medRxiv a license to display the preprint in perpetuity. It is made available under a CC-BY-NC-ND 4.0 International license .

Bastos, L. S., Oliveira, R., \& Velasque, L. (2015). Obtaining adjusted prevalence ratios from logistic regression models in cross-sectional studies. Cadernos de saude publica, 31(3), 487-495. https://doi-org.ces.idm.oclc.org/10.1590/0102-311x00175413

Bologna, L., Stamidis, K. V., Paige, S., Solomon, R., Bisrat, F., Kisanga, A., Usman, S., Arale, A. (2021). Why communities should be the focus to reduce stigma attached to COVID-19. The American Journal of Tropical Medicine and Hygiene, 104(1), 39-44. https://doi.org/10.4269/ajtmh.20-1329

Brooks, S. K., Webster, R. K., Smith, L. E., Woodland, L., Wessely, S., Greenberg, N., \& Rubin, G. J. (2020). The psychological impact of quarantine and how to reduce it: a rapid review of the evidence. The Lancet, 395(10227), 912-920. https://doi.org/10.1016/s01406736(20)30460-8

Campo-Arias, A., \& Ceballos-Ospino, G. A. (2019). Confirmatory factor analysis of the fiveitem version of the Francis scale of attitude towards Christianity in adolescent students. Journal of Beliefs \& Values, 41(1), 51-57. https://doi.org/10.1080/13617672.2019.1638877 Campo-Arias, A., \& Herazo, E. (2015). El complejo estigma-discriminación asociado a trastorno mental como factor de riesgo de suicidio [The stigma-discrimination complex associated with mental disorder as a risk factor for suicide]. Revista Colombiana de Psiquiatría, 44(4), 243-250. https://doi.org/10.1016/j.rcp.2015.04.003

Campo-Arias, A., Álvarez-Solorza, I., Tirado-Otálvaro, A. F., \& Cassiani-Miranda, C. A. (2020). Proposal of a scale for COVID-19 stigma-discrimination toward health workers. Journal of Investigative Medicine, 69(1), 100-101. https://doi.org/10.1136/jim-2020-001647

Campo-Arias, A., Ceballos-Ospino, G. A., \& Herazo, E. (2020). Barriers to access to mental health services among Colombia outpatients. International Journal of Social Psychiatry, 66(6), 600-606. https://doi.org/10.1177/0020764020925105

Cassiani-Miranda, C. A., \& Campo-Arias, A. (2020). Stigma-discrimination: Significant collateral damage of COVID-19. Indian Journal of Psychiatry, 62(5), 610-611. https://doi.org/10.4103/psychiatry.indianjpsychiatry_506_20

Cassiani-Miranda, C. A., Campo-Arias, A., Tirado-Otálvaro, A. F., Botero-Tobón, L. A., UpeguiArango, L. D., Rodríguez-Verdugo, M. S., Botero-Tobón, M. E., Arismendy-López, Y. A., Robles-Fonnegra, W. A., Niño, L., \& Scoppetta, O. (2020). Stigmatisation associated with 
medRxiv preprint doi: https://doi.org/10.1101/2021.03.14.21253547; this version posted March 17, 2021. The copyright holder for this preprint (which was not certified by peer review) is the author/funder, who has granted medRxiv a license to display the preprint in perpetuity. It is made available under a CC-BY-NC-ND 4.0 International license .

COVID-19 in the general Colombian population. International Journal of Social Psychiatry. https://doi.org/10.1177/0020764020972445

Cassiani-Miranda, C. A., Tirado-Otálvaro, A. F., \& Campo-Arias, A. (2021). Adaptation and psychometric evaluation of the COVID-19 Fear Scale in the general Colombian population. Death Studies, 1-8. Advance online publication. https://doi.org/10.1080/07481187.2021.1874572

Chopra, K. K., \& Arora, V. K. (2020). Covid-19 and social stigma: Role of scientific community. Indian Journal of Tuberculosis, 67(3), 284-285. https://doi.org/10.1016/j.ijtb.2020.07.012

Dar, S. A., Khurshid, S. Q., Wani, Z. A., Khanam, A., Haq, I., Shah, N. N., Shahnawaz, M., \& Mustafa, H. (2020). Stigma in coronavirus disease-19 survivors in Kashmir, India: A crosssectional exploratory study. PLoS One, 15(11), e0240152. https://doi.org/10.1371/journal.pone.0240152

Demidenko, E. (2007). Sample size determination for logistic regression revisited. Statistics in Medicine, 26(18), 3385-3397. https://doi.org/10.1002/sim.2771

Demirtaş-Madran H. A. (2020). Exploring the motivation behind discrimination and stigmatisation related to COVID-19: A social psychological discussion based on the main theoretical explanations. Frontiers in Psychology, 11, 569528. https://doi.org/10.3389/fpsyg.2020.569528

Erku, D. A., Belachew, S. A., Abrha, S., Sinnollareddy, M., Thomas, J., Steadman, K. J., \& Tesfaye, W. H. (2021). When fear and misinformation go viral: Pharmacists' role in deterring medication misinformation during the «infodemic»surrounding COVID-19. Research in Social and Administrative Pharmacy, 17(1), 1954-1963. https://doi.org/10.1016/j.sapharm.2020.04.032

Fischer, L. S., Mansergh, G., Lynch, J., \& Santibanez, S. (2019). Addressing disease-related stigma during infectious disease outbreaks. Disaster Medicine and Public Health Preparedness, 13(5-6), 989-994. https://doi.org/10.1017/dmp.2018.157

Goffman, E. (2009). Stigma: Notes on the management of spoiled identity. Simon and Schuster. Hashmi, F. K., Iqbal, Q., Haque, N., \& Saleem, F. (2020). Religious cliché and stigma: A brief response to overlooked barriers in COVID-19 management. Journal of Religion and Health, 59(6), 2697-2700. https://doi.org/10.1007/s10943-020-01063-y 
medRxiv preprint doi: https://doi.org/10.1101/2021.03.14.21253547; this version posted March 17, 2021. The copyright holder for this preprint (which was not certified by peer review) is the author/funder, who has granted medRxiv a license to display the preprint in perpetuity. It is made available under a CC-BY-NC-ND 4.0 International license .

Hernández, J. (2006). Selección del tamaño de muestra en estudios clínicos [Sample size selection in clinical studies]. Revista Colombiana de Gastroenterologia, 21(2), 118-121.

Hosmer, D. W., Taber, S., \& Lemeshow, S. (1991). The importance of assessing the fit of logistic regression models: a case study. American Journal of Public Health, 81(12), 1630-1635. https://doi.org/10.2105/ajph.81.12.1630

IBM Corp. (2015). IBM SPSS Statistics for Windows, Version 23.0. Armonk, NY: IBM Corp. Jeyaseelan, L., Kumar, S., Mohanraj, R., Rebekah, G., Rao, D., \& Manhart, L. E. (2013). Assessing HIV/AIDS stigma in South India: Validation and abridgement of the Berger HIV stigma scale. AIDS and Behavior, 17(1), 434-443. https://doi.org/10.1007/s10461-0110128-3

Katz, M. N. (2006). Multivariable analysis. Second edition. Cambridge: Cambridge University Press.

Link, B. G., \& Phelan, J. C. (2001). Conceptualising stigma. Annual Review of Sociology, 27(1), 363-385. https://doi.org/10.1146/annurev.soc.27.1.363

Liu, W., Yue, X.-G., \& Tchounwou, P. B. (2020). Response to the COVID-19 epidemic: The Chinese experience and implications for other countries. International Journal of Environmental Research and Public Health, 17(7), 2304. https://doi.org/10.3390/ijerph17072304

Mawar, N., Saha, S., Pandit, A., \& Mahajan, U. (2005). The third phase of HIV pandemic: social consequences of HIV/AIDS stigma \& discrimination \& future needs. The Indian journal of medical research, 122(6), 471-484.

Ministerio de Salud de Colombia. (1993). Resolución 008430 por la cual se establecen las normas científicas, técnicas y administrativas para la investigación en salud [Resolution 008430 by which the scientific, technical, and administrative standards for health research are established]. Santa Fe de Bogotá.

Monterrosa-Castro, A., Dávila-Ruiz, R., Mejía-Mantilla, A., Contreras-Saldarriaga, J., MercadoLara, M., \& Florez-Monterrosa, C. (2020). Estrés laboral, ansiedad y miedo al COVID-19 en médicos generales colombianos [Work stress, anxiety and fear of COVID-19 in Colombian general practitioners]. MedUNAB, 23(2), 195-213. https://doi.org/10.29375/01237047.3890 
medRxiv preprint doi: https://doi.org/10.1101/2021.03.14.21253547; this version posted March 17, 2021. The copyright holder for this preprint (which was not certified by peer review) is the author/funder, who has granted medRxiv a license to display the preprint in perpetuity. It is made available under a CC-BY-NC-ND 4.0 International license .

Mostafa, A., Sabry, W., \& Mostafa, N. S. (2020). COVID-19-related stigmatisation among a sample of Egyptian healthcare workers. PLoS One, 15(12), e0244172. https://doi.org/10.1371/journal.pone.0244172

Perry, P., Donini-Lenhoff, F. (2010). Stigmatisation complicates infectious disease management. The Virtual Mentor: VM, 12(3), 225-230. https://doi.org/10.1001/virtualmentor.2010.12.3.mhst1-1003

Qin, X., \& Song, L. (2021). Addressing stigma in the context of the COVID-19 outbreak: a social-ecological approach. Infection Control \& Hospital Epidemiology. https://doi.org/10.1017/ice.2020.1433

Ramaci, T., Barattucci, M., Ledda, C., \& Rapisarda, V. (2020). Social stigma during COVID-19 and its impact on HCWs outcomes. Sustainability, 12(9), 3834. https://doi.org/10.3390/su12093834

Ransing, R., Ramalho, R., de Filippis, R., Ojeahere, M. I., Karaliuniene, R., Orsolini, L., Pinto da Costa, M., Ullah, I., Grandinetti, P., Gashi Bytyçi, D., Grigo, O., Mhamunkar, A., El Hayek, S., Essam, L., Larnaout, A., Shalbafan, M., Nofal, M., Soler-Vidal, J., PereiraSanchez, V., \& Adiukwu, F. (2020). Infectious disease outbreak related stigma and discrimination during the COVID-19 pandemic: Drivers, facilitators, manifestations, and outcomes across the world. Brain, Behavior, and Immunity, 89, 555-558. https://doi.org/10.1016/j.bbi.2020.07.033

Roelen, K., Ackley, C., Boyce, P., Farina, N., Ripoll, S. (2020). COVID-19 in LMICs: The need to place stigma front and centre to its response. The European Journal of Development Research, 32(5), 1592-1612. https://doi.org/10.1057/s41287-020-00316-6

Saeed, F., Mihan, R., Mousavi, S. Z., Reniers, R. L., Bateni, F. S., Alikhani, R., \& Mousavi, S. B. (2020). A narrative review of stigma related to infectious disease outbreaks: What can be learned in the face of the Covid-19 pandemic?. Frontiers in Psychiatry, 11, 565919. https://doi.org/10.3389/fpsyt.2020.565919

Schoch-Spana, M., Bouri, N., Rambhia, K. J., \& Norwood, A. (2010). Stigma, health disparities, and the 2009 H1N1 influenza pandemic: How to protect Latino farmworkers in future health emergencies. Biosecurity and Bioterrorism: Biodefense Strategy, Practice, and Science, 8(3), 243-254. https://doi.org/10.1089/bsp.2010.0021 
medRxiv preprint doi: https://doi.org/10.1101/2021.03.14.21253547; this version posted March 17, 2021. The copyright holder for this preprint (which was not certified by peer review) is the author/funder, who has granted medRxiv a license to display the preprint in perpetuity. It is made available under a CC-BY-NC-ND 4.0 International license .

Schwartz, K. L., Achonu, C., Buchan, S. A., Brown, K. A., Lee, B., Whelan, M., Wu, J. H. C., \& Garber, G. (2020). Epidemiology, clinical characteristics, household transmission, and lethality of severe acute respiratory syndrome coronavirus-2 infection among healthcare workers in Ontario, Canada. PLoS One, 15(12), e0244477. https://doi.org/10.1371/journal.pone.0244477

Smith, L. G. E., Gibson, S. (2020). Social psychological theory and research on the novel coronavirus disease (COVID $\square 19$ ) pandemic: Introduction to the rapid response special section. British Journal of Social Psychology, 59(3), 571-583. https://doi.org/10.1111/bjso.12402

Sorokin, M. Y., Kasyanov, E. D., Rukavishnikov, G. V., Makarevich, O. V., Neznanov, N. G., Morozov, P. V., Lutova, N. B., \& Mazo, G. E. (2020). Stress and stigmatisation in healthcare workers during the COVID-19 pandemic. Indian Journal of Psychiatry, 62(Suppl. 3), S445-S453. https://doi.org/10.4103/psychiatry.IndianJPsychiatry_870_20

Sotgiu, G., Dobler, C. C. (2020). Social stigma in the time of coronavirus disease 2019. European Respiratory Journal, 56(2), 2002461. https://doi.org/10.1183/13993003.024612020

Stangl, A. L., Earnshaw, V. A., Logie, C. H., van Brakel, W., C Simbayi, L., Barré, I., \& Dovidio, J. F. (2019). The health stigma and discrimination framework: A global, crosscutting framework to inform research, intervention development, and policy on healthrelated stigmas. BMC Medicine, 17(1), 31. https://doi.org/10.1186/s12916-019-1271-3

Teksin, G., Uluyol, O. B., Onur, O. S., Teksin, M. G., \& Ozdemir, H. M. (2020). Stigma-related factors and their effects on healthcare workers during COVID-19 pandemics in Turkey: A Multicenter Study. Sisli Etfal Hastanesi tip Bulteni, 54(3), 281-290.

https://doi.org/10.14744/SEMB.2020.02800

Ugidos, C., López-Gómez, A., Castellanos, M. Á., Saiz, J., González-Sanguino, C., Ausín, B., \& Muñoz, M. (2020). Evolution of intersectional perceived discrimination and internalized stigma during COVID-19 lockdown among the general population in Spain. International Journal of Social Psychiatry. https://doi.org/10.1177/0020764020975802

Upegui-Arango, L. D., \& Orozco Vargas, L. C. (2019). Estigma hacia la tuberculosis: validación psicométrica de un instrumento para su medición [Stigma towards tuberculosis: 
medRxiv preprint doi: https://doi.org/10.1101/2021.03.14.21253547; this version posted March 17, 2021. The copyright holder for this preprint (which was not certified by peer review) is the author/funder, who has granted medRxiv a license to display the preprint in perpetuity. It is made available under a CC-BY-NC-ND 4.0 International license.

psychometric validation of an instrument for its measurement]. Anales de la Facultad de Medicina, 80(1), 12-20. https://doi.org/10.15381/anales.v80i1.15656

Wajahat, H. (2020). Role of social media in COVID-19 pandemic. The International Journal of Frontier Sciences, 4(2), 59-60. https://doi.org/10.37978/tijfs.v4i2.144

World Medical Association. (2018). Declaration of Helsinki. Seoul, Korea: WMA. 